\title{
大学英语课程教学中融入爱国主义教育的重要性
}

\author{
陈益旭 \\ 云南师范大学外国语学院 \\ DOI:10.32629/jief.v2i7.1891
}

[摘 要] 爱国主义教育是思想政治教育的重要内容, 对于当代大学生的爱国主义教育尤为必要。大学英语课程虽说学习的都是外语语言知识, 但是思想政治教育始终贯穿于每一门学科。在大学英语教学中, 教师不单要传授基本知识和基本技能, 更要深度挖掘隐藏在教材中的育人价 值。坚持传授知识与思想教育相结合的规律。

[关键词] 爱国主义教育; 大学课程教学; 重要性

中图分类号: G633.41 文献标识码: A

\section{1 爱国主义教育融入大学英语课程教学的意义体现}

1.1 爱国主义教育融入大学英语课程教学是思想政治教育的必然要 求

习主席强调, 高校思想政治工作关系高校培养什么样的人、如何培 养人以及为谁培养人这个根本问题。要坚持把立德树人作为中心环节, 把思想政治工作贯穿教育教学全过程。思想政治教育对于国家人才培养 具有十分重大的意义, 党和国家高度重视高校教育当中的思想政治教育 工作。从目前我国高校思想政治教育的现状来看, 大多学校重视程度还 不够, 思想政治教育工作主要集中在学校专门开设的思政课程当中, 由 于人数多, 课时少等原因, 其落实效果往往不佳。这就需要将思想政治 教育融入其他课程教学当中, 扩宽其落实渠道, 取得最佳成效。作为思 想政治教育中的核心内容, 爱国主义教育具有举足轻重的作用。爱国主 义教育是提高全民族整体素质的基础性工程, 是引导人们特别是广大大 学生树立正确理想、信念、人生观、价值观, 促进中华民族振兴的一项 重要工作。在大学英语课程教学当中, 学生们接触到的大多都是西方文 化和西方价值观念, 由于历史和文化的差异, 必然会产生矛盾和冲突。 不少学生会在这过程当中感到迷茫和困惑, 甚至是产生了崇洋媚外的错 误思想, 总是觉得西方的太阳总是比东方的圆。因此, 英语课程中的爱 国主义教育必不可少。只有将爱国主义教育融入其中, 才能确保学生们 端正立场, 明确方向。始终将自己视为会主义事业的拥护者和建设者。 由此可见, 将爱国主义教育融入大学英语课程教学是深入落实思想政治 教育的重要体现。

1.2 爱国主义教育是提升大学生文化自信的有效途径

“文化是民族生存和发展的重要力量。人类社会每一次跃进, 人类文 明每一次升华, 无不伴随着文化的历史性进步。人无精神则不立, 国无 精神则不强。一个国家、一个民族要屹立于世界民族之林, 都离不开文 化的积极引领。然而, 文化自信的提升离不开爱国主义教育。在传统的 教育观念中爱国主义教育往往会被人们局限地划分到专门的思想政治教 育课程中。在其他课程中则无需体现, 尤其是外语课程, 涉及到的主要 是英语国家的思想文化和价值观念, 本国的爱国主义教育在英语课程教 学中是不切实际的。正是由于这样的错误观念使得我国的爱国主义教育 在外语教学中失去了本该有的地位。导致许多大学生在接触外来文化时, 总会觉得西方的文化要比我们国家的好, 而我们的民族文化总是与落后 相匹配。随着我国发展进入了新的历史阶段, 树立大国形象, 展现民族 自信越来越成为国家的需要。爱国主义教育融入大学英语课程教学当中, 促使大学生传统角色的转变。带着对于祖国的无限热爱之情, 他们已不 再是纯粹的外来文化接收者和传递者, 在新的时代背景下, 学习和掌握 了外语知识之后大学生更应当充当本国文化的宣传者, 将我国的优秀传 统文化传播到世界各地, 让各国人民感受我国文化的深厚历史底蕴和精 髓，从而树立起中国大国形象，展现出中华民族强大的民族自信心。 1.3 当前大学生的爱国主义觉悟需要提高
语言是文化的载体, 学习英语必然会涉及西方文化和价值理念。但 是, 对于西方文化我们不能未经笁选就全盘接受, 而将我国数千年沉淀 下来的民族精髓弃之不顾。在英语教育中融合爱国主义教育既是英语教 育的重要内容和任务, 也是爱国主义教育必须重视的一个环节。倘若英 语教育不能与爱国主义教育有机融合, 爱国主义教育必然大打折扣, 英 语教育方向也会令人担忧。当前的大学英语课程教学对于大学生的要求 不应当仅仅局限在知识的掌握和技能的提高上, 更应当融入新的教育理 念, 将爱国主义教育渗入其中, 从而增强每一位大学生的爱国主义意识, 促进大学生对于本国文化的学习, 理解, 和认同。新时代背景下, 我国 大学生在国家发展和建设中扮演着中流砥柱的作用, 他们的思想素质直 接关乎国家和民族的前途命运, 培养他们的爱国主义精神, 提高他们的 爱国主义觉悟, 有利于帮助他们树立正确的世界观、人生观和价值观, 把个人利益与国家的前途、命运联系在一起, 正确处理好国家、集体、 个人三者利益关系, 为国家和民族而刻苦学习。

\section{2 结束语}

当代大学生正处于国家发展的关键时期, 肩负着实现中华民族伟大 复兴梦的神圣使命。加强大学生的爱国主义教育, 提升大学生的爱国主 义意识是高等教育工作中的重中之重。爱国不是一个口号, 更是一种落 实到具体的实际行动。在大学英语课程教学当中融入爱国主义教育有利 于激发大学生队伍的爱国热情, 促使他们能够刻苦努力, 奋发图强, 把 自身命运和国家发展紧密联系, 自觉将所学到的英语知识转化到祖国的 社会主义建设当中。我们有足够的理由相信, 富有爱国主义精神, 又具 备熟练英语技能的大学生人才队伍一定会在实现中华民族伟大复兴梦的 征程中凸显价值, 大有作为。

\section{[参考文献]}

[1]陈歆.大学英语课堂教学中思政教育的融合实践 [J].智库时 代,2019(49):62-63.

[2]李洁.新时代大学生的历史使命与英语学习探析[J]. 教书育人(高 教论坛),2019(03):101-103.

[3]吴比. 在英语教育中融入爱国主义的思考 [J]. 思想战 线,2010,36(S2):253-255.

[4]徐汉滨. 论新时代大学生思想政治教育的新要求和新路径 [J].湖 南大众传媒职业技术学院学报,2018,18(03):92-95.

[5]叶枫.论大学英语教育中本土文化的缺乏及其对策[J].陕西教育 (高教),2016(10):18-19.

[6]杨晓红.新媒体时代大学生文化自信的培育方法探析[J].大众文 艺,2019(21):228-229.

[7]赵杨银涛. 大学英语本土文化教育意识的培养[J]. 黑龙江生态工 程职业学院学报,2018,31(03): 139-140+143.

作者简介: 陈益旭（1994-), 男, 汉族, 广西风山人, 云南师 范大学外国语学院 19 级硕士研究生, 研究方向为英语教学。 